\title{
Use of oriental melon peel extracts to maintain the quality of Agaricus bisporus during its storage
}

\author{
Hye Jin Park, Gun-Hee Kim* \\ Department of Food and Nutrition, Duksung Women's University, Seoul 132-714, Korea
}

\section{참외과피추출물을 적용한 양송이의 저장 중 품질 변화}

\author{
박혜진 · 김건희* \\ 덕성여자대학교 식품영양학과
}

\begin{abstract}
Changes in quality of mushroom during storage are severe problem that reduce the shelf life of harvested mushrooms. This study investigates the effect of oriental melon peel extracts on maintenance of the quality of mushrooms (Agaricus bisporus). Mushrooms were dipped in solutions (distilled water, DW; 0.1\% oriental melon peel extract, OMP; $0.1 \%$ ascorbic acid, AA; and OMP+AA) for 3 minutes. After the dipped mushrooms were air-dried at room temperature, they were packaged in a polypropylene (PP) films and stored at $4^{\circ} \mathrm{C}$ and $15^{\circ} \mathrm{C}$. The changes in the quality of mushrooms were measured in terms of their color, gas composition, firmness, and sensory evaluation during storage at $4^{\circ} \mathrm{C}$ and $15^{\circ} \mathrm{C}$. The antioxidant and anti-browning activities of oriental melon peel extract were measured with respect to their total polyphenol contents, total flavonoid contents, DPPH, ABTS radical scavenging, copper chelating activity and PPO inhibition activity. The samples that were dipped in all the solutions did not show significant differences in firmness and gas exchange during their storage at $4^{\circ} \mathrm{C}$ and $15^{\circ} \mathrm{C}$. At both storage temperatures, the OMP solution samples showed highest $\mathbf{L}$ value and lowest delta $\mathbf{E}$ value. The sensory evaluation showed that during the storage period, the overall acceptability of mushrooms treated with the OMP and OMP+AA solutions was higher than that of the untreated mushrooms. The total polyphenol and flavonoid contents of oriental melon peel extract were $4.81 \mathrm{mg} \mathrm{GAE} \cdot \mathrm{g}^{-1}$ and $1.18 \mathrm{mg} \mathrm{QE} \cdot \mathrm{g}^{-1}$, respectively. The $\mathrm{DPPH}$, ABTS radical scavenging activity, copper chelating activity and PPO inhibition activity of the oriental melon peel extract lower than ascorbic acid. All these results suggest that oriental melon peel extract can be used as a natural browning inhibitor.
\end{abstract}

Key words : Agaricus bisporus, quality, oriental melon peel, browning inhibitor

\section{서 론}

버섯은 탄수화물, 단백질 및 무기질 등의 영양소를 골고 루 함유하고 있으며 특유의 향미를 지니고 있다(1). 국내에 서는 양송이, 느타리 등 12 종이 재배되고 있으며 양송이는 4계절 연중 수확되는 버섯으로 국내에서 1960년대부터 재 배되기 시작하여 2011년도 양송이의 생산량은 총 버섯 생 산량의 약 $8 \%$ 정도인 13,052톤으로 꾸준히 생산되고 있다 (2). 양송이의 유통기간은 2 3일 정도로 다른 과채류에 비 해 조직이 취약하고 호흡속도가 빠르기 때문에 수확 후 저장 및 유통과정 중의 품질변화가 일어나기 쉽다(3).

*Corresponding author. E-mail : ghkim@duksung.ac.kr Phone : 82-2-901-8496, Fax : 82-2-901-8474
양송이의 저장 중 품질변화를 방지하기 위하여 예냉처리 (4), 포장재질에 따른 기체조성조절(5) 등의 연구가 진행되 어왔는데 $\operatorname{Kim}$ 등(4)의 연구에서는 수확 후 예냉처리가 양 송이의 저장 중 품질유지에 효과적이었고, Chang 등(5)의 연구에서는 양송이를 polypropylene(PP) film으로 포장하였 을 경우 상품성이 더 오래 유지된다고 밝혔다. 또한, 양송이 의 저장 중 품질저하는 표면의 갈변현상으로 나타나며 이는 주로 양송이에 함유된 polyphenol oxidase(PPO)의 한 종류 인 tyrosinase에 의한 것으로 알려져있다(6). Tyrosinase를 저해하는 것으로 알려진 ascorbic acid, citric acid, cysteine 등의 천연유래물질의 갈변저해효과를 확인하는 많은 연구 (7-9)가 진행되었지만 최근 소비자의 천연소재에 대한 관심 
의 증가로 감국, rhubarb juice 등 천연소재 추출물의 갈변저 해효과에 대한 연구가 활발하게 진행되고 있다(10-12).

참외(Cucumis melo L.)는 박과(Cucurbitaceae)류에 속하 는 식물로 멜론(Cucumis melo L.)에서 유래한 것으로 알려 져 있으며 현재는 주로 우리나라를 비롯하여 중국, 일본 등지에서 재배되고 있다(13). 참외에는 vitamin $\mathrm{C}$ 가 다량으 로 함유되어있는 것이 특징이며 참외에 함유되어 있는 당은 인체에 흡수가 빨라 피로 회복에 효과적이며 cucurbitacin과 같은 항암성분을 함유하고 있다(38). 우리나라에서는 주로 과육 및 태좌부분을 섭취하고, 과피는 버리고 있으나 최근 연구에 의하면 총 페놀 및 플라보노이드 함량과 항산화 활성 그리고 tyrosinase 저해활성은 과육과 태좌부위에 비해 과피에서 더 높은 것으로 확인되었다(14).

본 연구에서는 식품부산물인 참외과피를 천연갈변저해 제로서 적용할 수 있는지 그 가능성을 검토하기 위해 참외 과피추출물 및 ascorbic acid를 단독 또는 병용으로 적용한 양송이의 저장 중 품질변화를 조사하였다.

\section{재료 및 방법}

양송이

본 실험에 사용한 양송이는 백색종으로 경기도 용인시 농가에서 재배, 수확된 것으로 사용하였다. 수확 직후 2 $\mathrm{kg}$ expandable polystyrene(EPS) 상자에 포장한 상태에서 2 시간 내로 실험실로 운반하여 4 시간 동안 $4^{\circ} \mathrm{C}$ 에서 예냉처 리 하였고, 양송이는 외관 상태와 모양이 전체적으로 균일 한 것을 선별하여 시료로 사용하였다.

\section{추출물 제조}

천연소재로 사용한 참외(Cucumis melo L.)는 경상북도 성주산으로 2013년 09월에 경동시장에서 구매하여 이용하 였다. 참외는 과피 부분을 분리, 세절하여 동결건조 한 후, 시료 $100 \mathrm{~g}$ 과 $70 \%$ ethanol $1 \mathrm{~L}$ 를 혼합한 뒤 $80^{\circ} \mathrm{C}$ 의 진탕수조 에서 9 시간동안 1 회 추출하였다. 추출액은 회전감압농축기 (N-1000, Tokyo Rikakikai Co., Ltd., Eyela, Japan)로 농축한 후 분말화하여 $-20^{\circ} \mathrm{C}$ 에 보관하며 사용하였다.

\section{시료처리 및 저장조건}

$0.1 \%$ 참외과피추출물과 $0.1 \%$ ascorbic acid를 단독 또는 병용처리하기 위하여 각 용액을 $10 \mathrm{~L}$ 씩 준비하여 $4 \mathrm{~kg}$ 의 양송이를 3 분간 침지 시킨 후 1 시간 동안 실온에서 건조하 였다. 준비된 양송이는 PP film $(21.5 \times 11.5 \mathrm{~cm}, 30 \mu \mathrm{m})$ 에 약 $100 \mathrm{~g}$ 씩 담은 후 전기접착기(SK-210, SB Tech, Seoul, Korea)로 밀봉하여 포장하였다. 모든 처리구는 $4,15^{\circ} \mathrm{C}$ 에서 저장하며 3 일 간격으로 품질변화를 측정하였다.

\section{기체조성}

양송이 포장 내 head space 기체를 가스 기밀성 주사기로 취한 후 oxygen/carbon dioxide headspace analyzer(6600, Illinois Instruments, Inc., Johnsburg, Il, USA)를 이용하여 분석하여 백분율(\%)로 나타내었다(28).

경 도

저장기간 중 양송이의 경도측정은 texture analyser (TA1, LLOYD Instrument, Ametek, Inc., Largo, Fl, USA)를 이용하 여 depression limit $10 \mathrm{~mm}$, test speed $50 \mathrm{~mm} / \mathrm{min}$, trigger $0.1 \mathrm{~N}$ 의 조건에서 측정하였다(5).

\section{색도 및 외관변화}

표면색은 표준백판( $\mathrm{L}=97.40, \mathrm{a}=-0.49, \mathrm{~b}=1.96)$ 으로 보정 된 chromameter(CR-400, Minolta Co., Osaka, Japan)를 사용 하여 측정하였으며, 시료 갓의 상단 중심부위를 10 반복으 로 Hunter 색차계인 $\mathrm{L}, \mathrm{a}$ 및 $\mathrm{b}$ 값을 측정하였다. 각 처리구간 의 색도의 차이는 색차(color difference, $\Delta \mathrm{E})$ 를 이용하여 분석하였으며 계산식은 다음과 같다(11).

$$
\Delta \mathrm{E}=\left(\Delta \mathrm{L}^{2}+\Delta \mathrm{a}^{2}+\Delta \mathrm{b}^{2}\right)^{1 / 2}
$$

\section{관능평가}

관능평가는 Minamide 등(15)과 $\operatorname{Kader}(16)$ 의 방법을 응용 하여 색, 냄새, 갓 개열 정도, 조직감, 전체적인 기호도 등 총 5 가지 항목을 9점 척도로 평가하였으며 $(n=12)$, 전체적인 기호도 5점까지를 저장수명의 한계로 설정하였다. 가장 높 은 점수인 9점은 아주 신선한 상태(fresh)를 나타내며, 7점 은 좋은 상태(good), 5점은 판매가능 한 상태(salable), 3점은 판매가능하지 않으나 섭취 가능한 상태(edible), 1점은 섭취 할 수 없는 상태(not edible)를 나타내었다.

\section{총 페놀 함량 측정}

총 페놀 함량은 페놀성 물질인 phosphomolybdic acid와 반응하여 청색을 나타내는 원리를 이용한 Folin-Denis 방법 (17)을 이용하여 측정하였다. $10 \mathrm{mg} / \mathrm{mL}$ 농도로 methanol에 용해시킨 시료액 $50 \mu \mathrm{L}$ 와 Folin-Ciocalteu's phenol reagent (Sigma, Chemical Co., St. Louis, MO, USA) $50 \mu \mathrm{L}$ 를 첨가하 여 혼합한 후 3 분간 실온에서 반응시킨 뒤, $10 \%$ sodium carbonate $\left(\mathrm{Na}_{2} \mathrm{CO}_{3}\right)$ 용액 $150 \mu \mathrm{L}$ 를 가하여 암실에서 1시간 동안 방치하여 $760 \mathrm{~nm}$ 에서 흡광도를 측정하였다. Gallic $\operatorname{acid(Sigma,~Chemical~Co.)ㄹㅡㄹ~ㅇㅣㅇㅛㅇㅎㅏㅇㅕ~ㄱㅓㅁㄹㅑㅇㅅㅓㄴㅇㅡㄹ~ㅈㅏㄱㅅㅓㅇㅎㅏㅇㅕㅆ~}$ 고 총 페놀 함량은 건조 시료 중량 당 $\mathrm{mg}$ gallic acid equivalent(mg GAE/g of dry weight, dw)로 나타내었다.

총 플라보노이드 함량 측정

시료 속에 함유된 총 플라보노이드 함량은 $\operatorname{Lin}$ 등(18)의 
방법을 일부 변경하여 측정하였으며 시료의 추출은 총 페놀 함량의 전처리와 동일한 방법을 적용하였다. 추출물 100 $\mu \mathrm{L}$ 에 $2 \%$ aluminium chloride $\left(\mathrm{AlCl}_{3}\right) 100 \mu \mathrm{L}$ 를 혼합하여 15 분간 방치한 후 반응액의 흡광도값을 $430 \mathrm{~nm}$ 에서 측정하였 다. 표준물질로 qercetin(Sigma, Chemical Co.)를 이용하여 검량선을 작성하였고 플라보노이드 함량은 건조 시료 중량 당 $\mathrm{mg}$ quercetin equivalent( $\mathrm{mg} \mathrm{QE} / \mathrm{g}$ of $\mathrm{dw}$ )로 나타내었다.

\section{$\mathrm{DPPH}$ 라디칼 소거 활성}

항산화활성은 1,1-diphenyl-2-picrylhydrazyl(DPPH, Sigma, Chemical Co.)를 이용하여 시료의 라디칼 소거효과(radical scavenging effect)를 측정하는 DPPH법(19)을 활용하였다. 각 농도별로 제조한 추출물 $100 \mu \mathrm{L}$ 에 $0.6 \mathrm{mM} \mathrm{DPPH} 100$ $\mu \mathrm{L}$ 를 가하고, 실온에서 30 분간 반응시킨 후 분광광도계를 이용하여 $515 \mathrm{~nm}$ 에서 흡광도를 측정하였다. 측정된 흡광도 를 아래의 식에 대입하여 라디칼 소거활성을 계산하고 추출 물을 첨가하지 않은 대조군의 값보다 $50 \%$ 의 활성을 보이는 추출물의 농도 $(\mathrm{EC} 50, \mathrm{mg} / \mathrm{mL})$ 로 나타냈다.

Radical scavenging activity $(\%)=(1-[\mathrm{A}-\mathrm{B} / \mathrm{C}-\mathrm{D}]) \times 100$ $\mathrm{A}$ : sample+시약, B: sample, C: blank+시약, D: blank

\section{ABTS 라디칼 소거 활성}

ABTS radical scavenging activity의 측정은 Pellegrin 등 (20)의 방법에 의해 측정하였다. 즉, $7 \mathrm{mM} \mathrm{2,2'-azinobis}$ (3-ethylbenzthiazoline-6-sulfonoc acid) (ABTS, Sigma, Chemical Co.)와 $2.45 \mathrm{mM}$ potassium persulfate $\left(\mathrm{K}_{2} \mathrm{~S}_{2} \mathrm{O}_{8}\right)$ 을 섞어 어두운 곳에 16 시간 방치시킨 후, 이를 absolute ethanol 로 희석하여 $734 \mathrm{~nm}$ 에서 대조구의 흡광도 값이 $0.7 \pm 0.02$ 가 되도록 조절한 ABTS solution을 사용하였다. 각 농도별의 추출물 $20 \mu \mathrm{L}$ 와 ABTS solution $180 \mu \mathrm{L}$ 를 1분간 방치 후 $734 \mathrm{~nm}$ 에서 흡광도를 측정하였다. 측정된 흡광도를 아래의 식에 대입하여 라디칼 소거활성을 계산하고 추출물을 첨가 하지 않은 대조군의 값보다 $50 \%$ 의 활성을 보이는 추출물의 농도 $\left(\mathrm{EC}_{50}, \mathrm{mg} / \mathrm{mL}\right)$ 로 나타냈다.

Radical scavenging activity $(\%)=(1-[\mathrm{A}-\mathrm{B} / \mathrm{C}-\mathrm{D}]) \times 100$ $\mathrm{A}$ : sample+시약, B: sample, C: blank+시약, D: blank

\section{구리 $\left(\mathrm{Cu}^{2+}\right)$ 킬레이트 활성}

구리 킬레이트 활성은 pyrocatechol violet(PV)을 사용한 방법(21)으로 측정하였다. 각 추출물 $30 \mu \mathrm{L}$ 을 96-well plate 에 $4 \mathrm{mM}$ PV $6 \mu \mathrm{L}$ 와 $\mathrm{CuSO}_{4} \cdot 5 \mathrm{H}_{2} \mathrm{O}(50 \mu \mathrm{g} / \mathrm{ml}$, w/v) $100 \mu \mathrm{L}$ 를 혼합하고 $\mathrm{Na}$ acetate buffer(pH 6.0)를 첨가하여 $200 \mu \mathrm{L}$ 를 맞춰 주었다. 이 용액을 $632 \mathrm{~nm}$ 에서 microplate reader(M2, Molecular Device, Canada)를 이용하여 측정하고, 아래의 식에 대입하여 구리 킬레이트 활성을 계산하였다. 구리 킬
레이트 활성은 추출물을 첨가하지 않은 대조군의 값보다 $50 \%$ 의 활성을 보이는 추출물의 농도 $\left(\mathrm{EC}_{50}, \mathrm{mg} / \mathrm{mL}\right)$ 로 나타 냈다.

Chelating activity effect $(\%)=(1-[\mathrm{A}-\mathrm{B} / \mathrm{C}-\mathrm{D}]) \times 100$

A: sample+시약, B: sample, C: blank+시약, D: blank

Polyphenol oxidase(PPO) 저해 활성

갈변 효소인 $\mathrm{PPO}$ 저해 활성은 $50 \mathrm{mM}$ phosphate buffer(pH 6.5) $120 \mu \mathrm{L}$ 와 $\mathrm{PPO}(500$ units/mg) $20 \mu \mathrm{L}$ 을 혼합한 후 저해제를 $10 \mu \mathrm{L}$ 을 첨가하여 $25^{\circ} \mathrm{C}$ 로 조절된 항온수조에 서 15 분간 방치하고, 기질로서 L-DOPA $60 \mu \mathrm{L}$ 를 각각 첨가 한 후, microplate reader(M2, Molecular Device, Toronto, Canada)를 이용하여 $475 \mathrm{~nm}$ 에서 10 분간의 변화를 측정하 였다. 효소의 저해활성은 흡광도의 변화를 관찰한 후 curve 의 직선부위의 값을 이용하여 아래의 식에 의해 저해율을 계산하였다 $(22) . \mathrm{IC}_{50}(\mathrm{mg} / \mathrm{mL})$ 은 추출물을 첨가하지 않은 대조군의 값을 $50 \%$ 감소시키는 추출물의 농도를 나타내며, 기존의 항산화제인 ascorbic acid를 대조구로 사용하여 비교 하였다.

Inhibition of PPO activity $(\%)=(1-[\mathrm{A}-\mathrm{B} / \mathrm{C}-\mathrm{D}]) \times 100$

A: sample+시약, B: sample, C: blank+시약, D: blank

\section{통계처리}

본 실험에서 얻어진 결과는 SPSS 통계분석 프로그램 (19.0, SPSS Inc., Chicago, Il, USA)을 이용하여 평균치와 표준오차를 산출하였으며, ANOVA 중 Duncan's multiple test를 통하여 각 데이터 구간의 유의적인 차이를 분석하였 다 $(\mathrm{p}<0.05)$.

\section{결과 및 고찰}

기체조성 및 경도 변화

침지처리 및 저장온도별 포장 내 기체 조성을 확인한 결과는 Fig. 1 과 같다. 저장온도에 상관없이 산소의 농도는 저장 3 일 째 급격하게 감소하였고, $15^{\circ} \mathrm{C}$ 에서 저장한 경우 산소의 농도는 처리구별 차이가 없는 것으로 나타났다. 그 러나 $4^{\circ} \mathrm{C}$ 에서 저장했을 때 저장 3 일 후 $\mathrm{OMP}$ 처리구와 $\mathrm{OMP}+\mathrm{AA}$ 처리구의 산소농도가 다른 처리구보다 높게 나 타났으나 유의적인 차이는 없었다. 이산화탄소의 농도는 3 일 까지 급격히 증가하였다가 $15^{\circ} \mathrm{C}$ 에서 저장했을 때 3 일 이후로는 다소 감소하는 경향을 보였으며 $4^{\circ} \mathrm{C}$ 에서 저장했 을 때 3 일째 까지 증가한 후 비슷한 수준을 유지하였다. 저장 3 일 째 이산화탄소의 농도는 $15^{\circ} \mathrm{C}$ 에서 $19.43 \sim 21.53 \%$, $4^{\circ} \mathrm{C}$ 에서 $14.17 \sim 15.93 \%$ 으로 나타났으며 $4^{\circ} \mathrm{C}$ 에서 저장했을 
때보다 $15^{\circ} \mathrm{C}$ 에서 저장했을 때 더 많은 이산화탄소가 생성되 었다. 이는 Gorny 등(23)의 연구에서 보고된 내용과 같이 저장 온도가 높을수록 양송이의 호흡이 촉진된 것으로 보이 며 $4^{\circ} \mathrm{C}$ 에서 저장하는 것이 양송이의 선도유지에 효과적인 것으로 사료된다. $15^{\circ} \mathrm{C}$ 에서 침지처리에 따른 이산화탄소 농도의 차이는 저장 9 일 째 $\mathrm{OMP}+\mathrm{AA}>\mathrm{AA}>\mathrm{OMP}>\mathrm{UN}>\mathrm{DW}$ 순으로 나타났으나 처리구별 유의적인 차이는 없었다. $4^{\circ} \mathrm{C}$ 에서 저장한 경우 저장 12 일 째 $\mathrm{OMP}+\mathrm{AA}$ 처리구의 이산화 탄소 농도가 가장 높았지만 처리구별 차이가 없었다 $(\mathrm{p}<0.05)$. Chung 등 $(24)$ 의 연구에 의하면 ascorbic acid와 citric acid를 신선절단 딸기에 적용하였을 경우 호흡작용에 거의 영향을 미치지 않는 것으로 보고하였다. 이와 같이 본 연구에서도 다양한 침지처리가 양송이 표면에 코팅된 것이 아니라 내부로 흡수되었고, 저장온도 및 처리구별 모 두 같은 조건으로 포장하였기 때문에 침지처리가 양송이의 호흡에 미치는 영향은 미비하다고 판단된다.

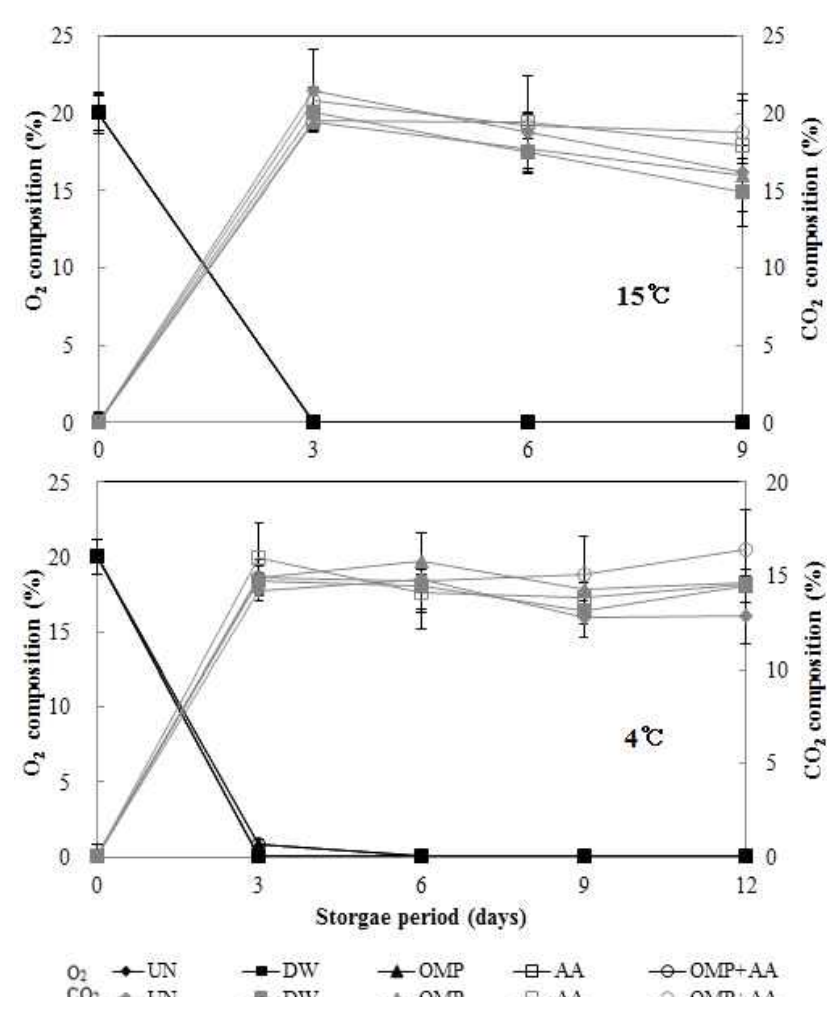

Fig. 1. Changes of $\mathrm{CO}_{2}$ and $\mathrm{O}_{2}$ concentration in packages of Agaricus bisporus dipped by various solutions during storage at 15 and $4{ }^{\circ} \mathrm{C}$.

UN: untreated; DW: distilled water; OMP: oriental melon peel extracts $0.1 \%$; AA: ascorbic acid $0.1 \%$; OMP+AA: $0.1 \%$ oriental melon peel extracts $+0.1 \%$ ascorbic acid.

양송이의 경도변화는 저장온도에 상관없이 저장 기간 동안 $16.57 \sim 22.38 \mathrm{~N}$ 사이에서 나타났다(Fig. 2). $15^{\circ} \mathrm{C}$ 에서 저장한 경우, 저장 6 일째 $\mathrm{UN}>\mathrm{OMP}>\mathrm{AA}>\mathrm{DW}>\mathrm{OMP}+\mathrm{AA}$ 순 으로 경도가 높게 나타났으며 저장 9일째 $\mathrm{OMP}+\mathrm{AA}$ 가 가장 높은 경도를 나타냈지만 다른 처리구와 유의적인 차이가
없었다. $4^{\circ} \mathrm{C}$ 에서 저장했을 때, 저장 6 일째 $\mathrm{OMP}$ 가 24.17 $\mathrm{N}$ 으로 다른 처리구에 비해 높은 경도를 나타냈으며 $(\mathrm{p}<0.05)$ 저장 후기에도 다소 높은 경도를 유지하였다. Wallner 등(25)의 연구결과에 따르면 과채류의 경도변화는 주로 pectinesterase 및 cellulase 등의 효소에 의한 것으로 산소의 농도가 이들 효소의 활성에 영향을 미치는 것으로 보고되었다. 따라서, 본 연구에서 산소의 농도가 처리구별 큰 차이가 없는 것으로 나타났기 때문에 경도변화에서도 침지처리에 따른 차이가 없었던 것으로 사료된다.
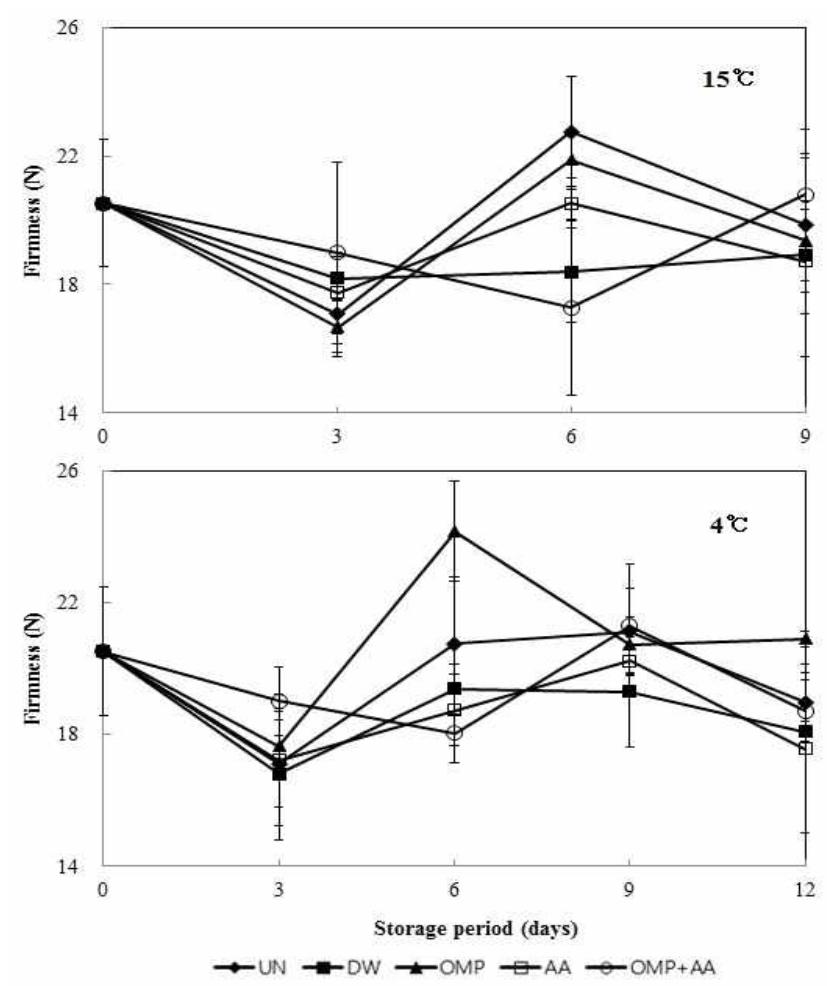

Fig. 2. Changes in firmness of Agaricus bisporus dipped by various solutions during storage at 15 and $4{ }^{\circ} \mathrm{C}$.

UN: untreated; DW: distilled water; OMP: oriental melon peel extracts $0.1 \%$; AA: ascorbic acid $0.1 \%$; OMP+AA: $0.1 \%$ oriental melon peel extracts $+0.1 \%$ ascorbic acid.

\section{색도 및 외관변화}

양송이의 갈변현상은 가공 및 유통과정 중에 쉽게 눈으 로 확인할 수 있는 품질요소이다. 본 실험에서는 참외과피 추출물을 갈변저해제로 처리하여 양송이의 색도 및 외관변 화를 관찰하였다. Fig. 3은 L값(ligtness)으로, 저장기간이 늘어남에 따라 감소하는 경향을 보였으며, Fig. 4는 전반적 인 색변화를 의미하는 $\mathbb{A}$ 값을 나타낸 것으로 저장기간이 경과함에 따라 점차 증가하였다. $\mathrm{L}$ 값의 경우, $15^{\circ} \mathrm{C}$ 에서 저 장하였을 때 저장기간 동안 $\mathrm{OMP}$ 처리구가 가장 높은 값을 유지하였다. 저장 후 6일 까지 85.84 87.78 사이의 값을 나타내며 처리구별 큰 차이 없었으나 저장 9일 째 무처리구 는 78.36 으로 가장 낮은 값을 나타냈고, OMP 처리구가 

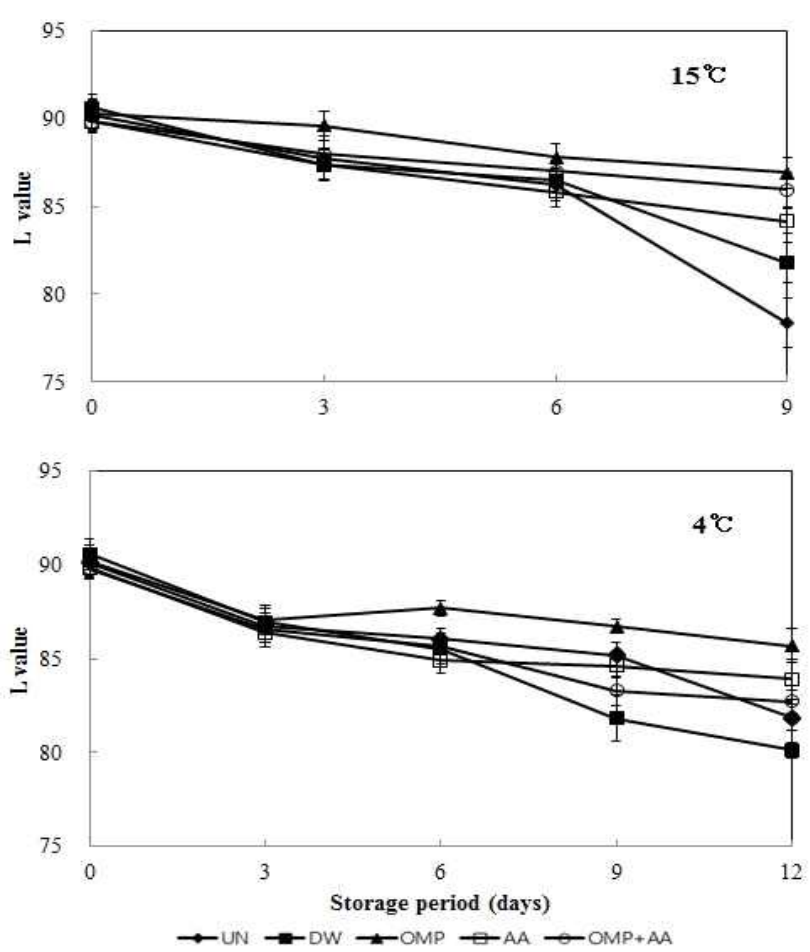

Fig. 3. Changes in Hunter L value of Agaricus bisporus dipped by various solutions during storage at 15 and $4^{\circ} \mathrm{C}$.

UN: untreated; DW: distilled water; OMP: oriental melon peel extracts $0.1 \%$; AA: ascorbic acid $0.1 \%$; OMP+AA: $0.1 \%$ oriental melon peel extracts $+0.1 \%$ ascorbic acid.
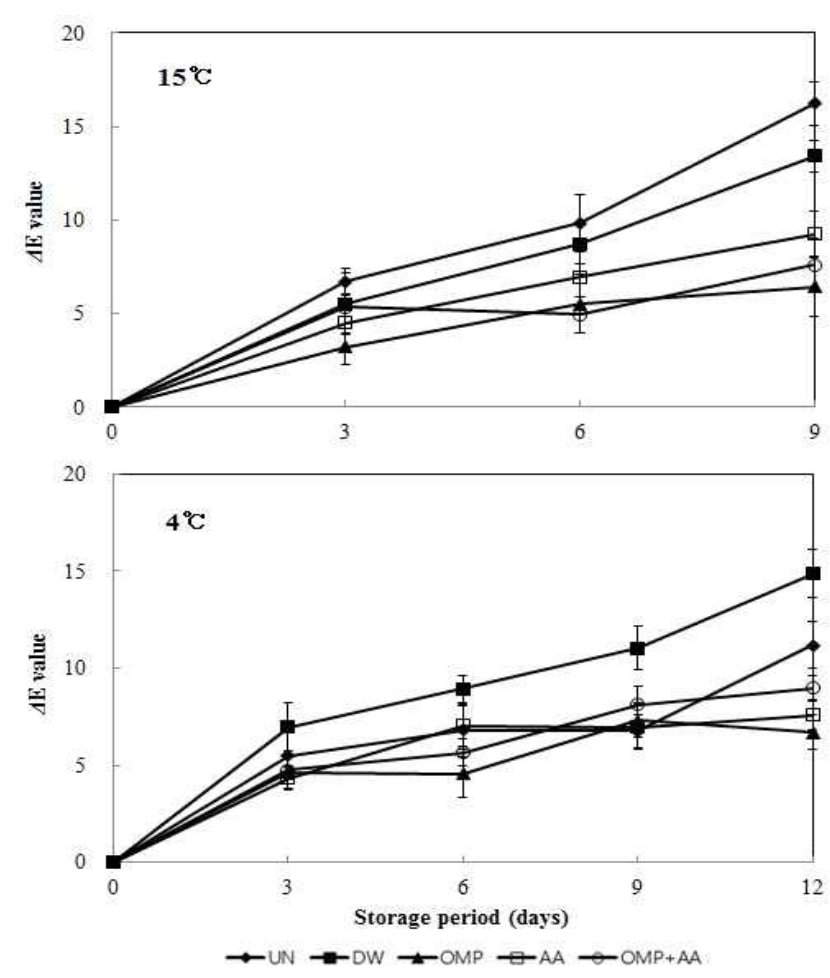

Fig. 4. Changes in $\Delta \mathrm{E}$ value of Agaricus bisporus dipped by various solutions during storage at 15 and $4{ }^{\circ} \mathrm{C}$.

UN: untreated; DW: distilled water; OMP: oriental melon peel extracts $0.1 \%$; AA: ascorbic acid $0.1 \%$; OMP+AA: $0.1 \%$ oriental melon peel extracts $+0.1 \%$ ascorbic acid.
86.90, OMP+AA 처리구가 85.92로 높은 L값을 유지하였다 $(\mathrm{p}<0.05) .4^{\circ} \mathrm{C}$ 에서 저장했을 경우 $15^{\circ} \mathrm{C}$ 에서와 마찬가지로 저장기간 동안 $\mathrm{OMP}$ 처리구가 가장 높은 값을 유지하였다. $4{ }^{\circ} \mathrm{C}$ 에서 저장 9 일 째 $\mathrm{OMP}$ 처리구가 86.72로 가장 높았고, $\mathrm{DW}$ 처리구가 81.83 으로 급격히 감소하였다. 저장 12 일 째 $\mathrm{OMP}>\mathrm{AA}>\mathrm{OMP}+\mathrm{AA}>\mathrm{UN}>\mathrm{DW}$ 순으로 높은 $\mathrm{L}$ 값을 유지 하였다. 80 이하의 $\mathrm{L}$ 값은 상품적 가치를 소실한다는 Lopez-Briones(26)의 보고에 따르면 본 연구결과에서 무처 리구(UN) 및 $\mathrm{DW}$ 처리구는 $15^{\circ} \mathrm{C}$ 에서 저장했을 때 9 일 이후 로 상품적 가치를 손실하였다.

$\Delta \mathrm{E}$ 값의 경우, $15^{\circ} \mathrm{C}$ 에서 저장했을 때 저장 6 일 째를 제외 하고 $\mathrm{OMP}$ 처리구가 가장 낮은 값을 나타냈으며, 저장 9 일 째 $\mathrm{OMP}>\mathrm{OMP}+\mathrm{AA}>\mathrm{AA}>\mathrm{DW}>\mathrm{UN}$ 순으로 낮은 값을 보이 며 $\mathrm{L}$ 값과 유사한 경향을 보였다. $4^{\circ} \mathrm{C}$ 에서 저장한 결과 저장 9일째를 제외하고 OMP 처리구가 가장 낮은 값을 유지했으 며 DW 처리구는 저장 12 일 째 14.86 으로 가장 높은 값을 나타냈다(p<0.05). 양송이의 외관변화는 Fig. 5 와 같으며 색도의 결과와 같이 $\mathrm{OMP}$ 와 $\mathrm{AA}$ 를 단독 또는 병용으로 처리 한 경우 무처리구와 DW 처리구에 비해 표면의 변색이 저해 된 것으로 확인되었다. 이를 통해 참외과피추출물을 양송 이에 적용하였을 때 표면색의 변화를 방지하여 기존의 유통 방법보다 품질유지기간을 연장시킬 수 있을 것으로 사료된 다. 과채류에서 발생하는 효소적 갈변을 억제하기위하여 황금(27), 백출(28) 등의 한약재 또는 다양한 과피추출물 (11)을 천연갈변저해제로서 적용하는 연구가 진행되어져 왔다. 백출추출물의 경우 양송이에 침지처리한 Lee 등(28) 의 연구결과에서 백출추출물과 L-cysteine을 병용으로 처리 한 양송이의 $\mathrm{L}$ 값이 가장 높게 유지되었고, $\Delta \mathrm{E}$ 값은 가장 낮게 유지되었다. 이는 추출물을 단독으로 처리했을 때 보 다 천연유래물질과 함께 처리했을 때 서로 상호 보완되어 효과적으로 갈변을 저해하는 것으로 보고하였다. 그러나 본 연구결과에서 양송이에 적용한 참외과피추출물이 ascorbic acid의 병용처리보다 추출물을 단독으로 처리하는 것이 더 효과적이었다.

\section{관능평가}

참외과피추출물 및 ascorbic acid를 단독 또는 병용처리 한 양송이의 저장 중 색변화, 갓 개열, 냄새, 조직감 및 전반 적인 기호도 등에 대한 관능평가의 결과를 저장온도에 따라 Table 1 및 Table 2 에 나타내었다. Table 1 은 $15^{\circ} \mathrm{C}$ 에서 저장 했을 때의 결과로 표면색의 경우, 저장 기간이 지남에 따라 다소 감소하는 경향을 보였으며 저장 3 일 이후 OMP 처리구 가 7점 이상을 유지하며 유의적으로 높은 값을 유지하였다 $(\mathrm{p}<0.05)$. 저장 9 일째 $\mathrm{OMP}$ 처리구와 $\mathrm{OMP}+\mathrm{AA}$ 처리구가 갈변방지에 효과적인 것으로 보였으며 이는 색도 및 외관변 화의 값과 일치하였다. 갓 개열의 경우 색변화에 비해 소폭 으로 감소하였으며 저장 기간 동안 처리구별 차이는 없었던 

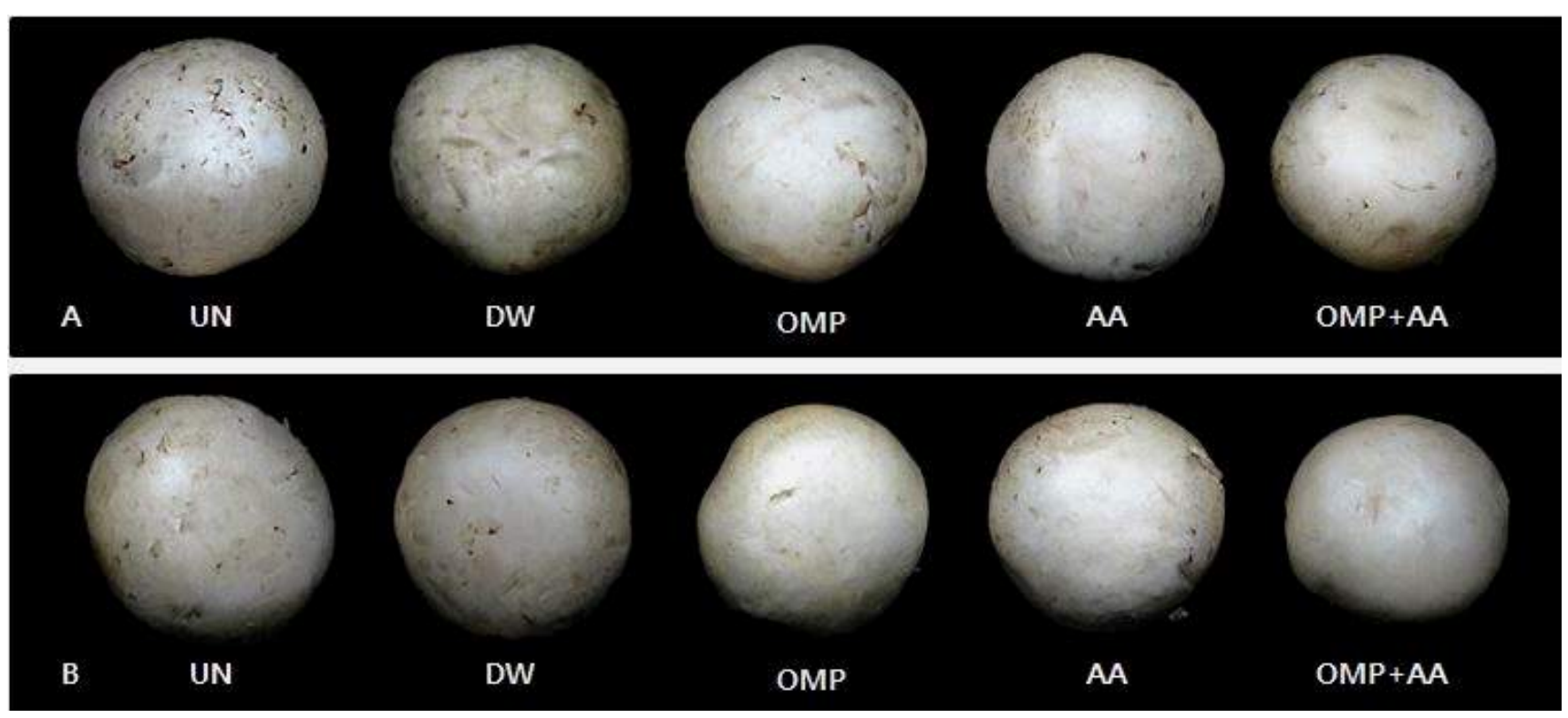

Fig. 5. Changes in appearance of Agaricus bisporus dipped by various solutions during storage at $15^{\circ} \mathrm{C}$ after 9 days (A) and storage at $4^{\circ} \mathrm{C}$ after 12 days (B).

UN: untreated; DW: distilled water; OMP: oriental melon peel extracts $0.1 \%$; AA: ascorbic acid $0.1 \%$; OMP+AA: $0.1 \%$ oriental melon peel extracts $+0.1 \%$ ascorbic acid.

것으로 나타났다. 양송이의 냄새는 저장 9 일 째, $\mathrm{OMP}$ 와 $\mathrm{OMP}+\mathrm{AA}$ 처리구가 다른 처리구에 비해 4점대로 높았으나 유의적인 차이는 없었던 것으로 보아 갈변저해제로 처리한 참외과피추출물 또는 ascorbic acid가 저장 중 발생하는 이 취에는 영향을 미치지 않는 것으로 판단된다. 조직감에 있 어서는 저장 9일 째 OMP 처리구가 가장 높았고, 무처리구 가 가장 낮은 값을 나타냈다. 전반적인 기호도는 저장 9 일 째 $\mathrm{OMP}$ 와 $\mathrm{OMP}+\mathrm{AA}$ 를 제외한 나머지 처리구가 5점 이하 의 값을 나타내며 상품성을 손실하였으며 OMP 처리구가 6.67 로 가장 높은 값을 나타냈다. $15^{\circ} \mathrm{C}$ 에서 저장 했을 때의 관능평가 결과를 토대로 참외과피추출물이 갈변방지 등에 서 효과적이었으며 양송이의 저장 중 품질유지에 긍정적인 영향을 미치는 것으로 사료된다. $4^{\circ} \mathrm{C}$ 에서 저장한 경우, 침지 처리별 관능평가 결과는 Table 2 와 같다. 관능평가 결과는 저장기간이 증가함에 따라 유의적으로 감소하는 경향을 보였으나 저장 12 일 째 냄새에 대한 결과를 제외하고 모두 5점 이상의 높은 값을 나타내며 처리구별 유의적인 차이를 보이지 않았다. 색변화에 있어서 OMP 및 OMP+AA 처리구 가 6.33으로 가장 높았고, 전반적인 기호도에 있어서 $\mathrm{OMP}$ 처리구의 값이 가장 높았다. 이와 같은 결과는 갈변저해제 처리에 따른 효과와 함께 저온에서 저장하는 것이 양송이의 품질을 유지하는데 효과적이라고 사료된다.

\section{총 페놀 및 플라보노이드 함량}

페놀성 화합물은 천연물에 널리 분포되어 있는 물질로 페놀성 화합물의 phenolic hydroxyl기를 통해 항산화, 항암 및 항균 등의 생리활성을 나타내는 것으로 보고된 바 있다
$(29,30)$. 플라보노이드 역시 다양한 식물에 함유되어 있으 며 항산화 등 기능성을 나타내는 성분으로서 최근 많은 연구가 진행되고 있다(31,32). Lee 등(33)의 연구에 따르면 과일껍질에 분포하는 페놀과 플라보노이드 사이에는 비교 적 높은 상관관계가 나타났으며 총 페놀함량이 높은 과일껍 질은 플라보노이드 함량도 비교적 높았다고 보고하였다. Table 3은 참외과피추출물의 총 페놀 및 플라보노이드 함량 을 나타낸 것으로 참외과피추출물의 총 페놀함량은 건조시 료 $\mathrm{g}$ 당 gallic acid의 등량값으로 나타낼 때 $4.81 \mathrm{mg}$ 이며, 플라보노이드는 quercertin 등량값으로 나타낼 때 건조 시료 $\mathrm{g}$ 당 $1.18 \mathrm{mg}$ 으로 측정되었다. Shin 등(14)의 연구결과에 의하면 참외과피의 총 페놀함량은 $224.77 \mathrm{\mu g} / \mathrm{mL}$, 플라보노 이드 함량은 $67.16 \mu \mathrm{gg} / \mathrm{mL}$ 로 본 연구결과와 같이 총 페놀함 량이 플라보노이드 함량보다 약 4 배가 높았으나 함량에 있어서는 다소 차이가 나타났다. 이는 시료의 추출방법에 따른 차이로 사료되며 총 페놀 함량은 과일의 품종, 숙성시 기, 표면 색 등에 따라 큰 차이를 나타내기 때문에(34) 측정 치간 결과가 다르게 나타날 수 있는 것으로 판단된다.

\section{라디칼 소거 활성}

유리 라디칼 물질인 DPPH와 $\mathrm{ABTS}$ 의 소거활성은 항산 화능을 나타내는 페놀성 물질의 함량과 유의적인 상관관계 를 보이나(35,36), 라디칼의 특징에 따라 DPPH 또는 ABTS 에서 활성을 보이지 않는 경우도 있기 때문에 본 연구에서 는 $\mathrm{DPPH}$ 와 $\mathrm{ABTS}$ 라디칼을 모두 측정하였다. $\mathrm{DPPH}$ 와 $\mathrm{ABTS}$ 라디칼의 $50 \%$ 소거활성을 나타내는 참외과피추출 물의 농도를 Table 4에 나타내었다. DPPH 라디칼 소거활성 
Table 1. Sensory properties of Agaricus bisporus dipped by various solutions during storage at $15^{\circ} \mathrm{C}$ for 9 days

\begin{tabular}{|c|c|c|c|c|c|}
\hline \multirow{2}{*}{ Attribute } & \multirow{2}{*}{ Sample } & \multicolumn{4}{|c|}{ Storage period (days) } \\
\hline & & 0 & 3 & 6 & 9 \\
\hline \multirow{5}{*}{ Color } & $\mathrm{UN}^{1)}$ & $9.00^{2(\mathrm{~A} 33 \mathrm{a} 4)}$ & $6.50^{\mathrm{Bbc}}$ & $4.20^{\mathrm{Cc}}$ & $4.00^{\mathrm{cb}}$ \\
\hline & DW & $8.50^{\mathrm{Aa}}$ & $7.50^{\mathrm{Aab}}$ & $5.00^{\mathrm{Bbc}}$ & $5.00^{\mathrm{Bab}}$ \\
\hline & OMP & $9.00^{\mathrm{Aa}}$ & $8.13^{\mathrm{ABa}}$ & $7.80^{\mathrm{ABa}}$ & $7.00^{\mathrm{BCa}}$ \\
\hline & $\mathrm{AA}$ & $8.50^{\mathrm{Aa}}$ & $5.38^{\mathrm{Bc}}$ & $4.40^{\mathrm{Bc}}$ & $4.00^{\mathrm{Bb}}$ \\
\hline & $\mathrm{OMP}+\mathrm{AA}$ & $8.50^{\mathrm{Aa}}$ & $7.00^{\mathrm{ABab}}$ & $6.40^{\mathrm{Bab}}$ & $6.67^{\mathrm{ABa}}$ \\
\hline \multirow{5}{*}{ Cap opening } & UN & $9.00^{\mathrm{Aa}}$ & $8.13^{\mathrm{ABa}}$ & $8.20^{\mathrm{ABa}}$ & $6.00^{\mathrm{Ba}}$ \\
\hline & DW & $9.00^{\mathrm{Ax}}$ & $8.38^{\mathrm{ABa}}$ & $8.40^{\mathrm{ABa}}$ & $6.00^{\mathrm{BCa}}$ \\
\hline & OMP & $9.00^{\mathrm{Aa}}$ & $8.25^{\mathrm{Aa}}$ & $8.40^{\mathrm{Aa}}$ & $6.00^{\mathrm{Ba}}$ \\
\hline & $\mathrm{AA}$ & $9.00^{\mathrm{Az}}$ & $8.38^{\mathrm{Aa}}$ & $8.20^{\mathrm{Aa}}$ & $6.00^{\mathrm{Ba}}$ \\
\hline & $\mathrm{OMP}+\mathrm{AA}$ & $9.00^{\mathrm{Az}}$ & $8.13^{\mathrm{ABa}}$ & $8.40^{\mathrm{ABa}}$ & $6.33^{\mathrm{BCa}}$ \\
\hline \multirow{5}{*}{ Odor } & UN & $9.00^{\mathrm{Ag}}$ & $6.38^{\mathrm{Ba}}$ & $6.00^{\mathrm{Ba}}$ & $3.33^{\mathrm{Ca}}$ \\
\hline & DW & $9.00^{\mathrm{Ax}}$ & $7.25^{\mathrm{ABa}}$ & $5.80^{\mathrm{Ba}}$ & $3.67^{\mathrm{Ca}}$ \\
\hline & OMP & $9.00^{\mathrm{Aa}}$ & $7.50^{\mathrm{ABa}}$ & $6.20^{\mathrm{Ba}}$ & $4.00^{\mathrm{Ca}}$ \\
\hline & $\mathrm{AA}$ & $9.00^{\mathrm{Aa}}$ & $6.50^{\mathrm{Ba}}$ & $5.60^{\mathrm{BCa}}$ & $3.67^{\mathrm{CDa}}$ \\
\hline & $\mathrm{OMP}+\mathrm{AA}$ & $9.00^{\mathrm{Ax}}$ & $6.50^{\mathrm{Ba}}$ & $5.20^{\mathrm{BCa}}$ & $4.33^{\mathrm{BCa}}$ \\
\hline \multirow{5}{*}{ Texture } & UN & $9.00^{\mathrm{Az}}$ & $8.00^{\mathrm{Ba}}$ & $5.80^{\mathrm{Ca}}$ & $4.00^{\mathrm{cb}}$ \\
\hline & DW & $9.00^{\mathrm{Ax}}$ & $7.63^{\mathrm{ABa}}$ & $6.40^{\mathrm{BCa}}$ & $5.00^{\mathrm{CDab}}$ \\
\hline & OMP & $9.00^{\mathrm{Aa}}$ & $8.00^{\mathrm{ABa}}$ & $7.00^{\mathrm{ABa}}$ & $6.33^{\mathrm{BCa}}$ \\
\hline & AA & $8.75^{\mathrm{Aa}}$ & $7.38^{\mathrm{ABa}}$ & $5.40^{\mathrm{BCa}}$ & $4.67^{\mathrm{Cab}}$ \\
\hline & $\mathrm{OMP}+\mathrm{AA}$ & $8.75^{\mathrm{Aa}}$ & $6.38^{\mathrm{Ba}}$ & $6.20^{\mathrm{Ba}}$ & $5.00^{\mathrm{BCab}}$ \\
\hline \multirow{5}{*}{$\begin{array}{c}\text { Overall } \\
\text { acceptability }\end{array}$} & UN & $9.00^{\mathrm{Aa}}$ & $6.75^{\mathrm{Bab}}$ & $5.00^{\mathrm{Cc}}$ & $3.33^{\mathrm{CDb}}$ \\
\hline & DW & $9.00^{\mathrm{Aa}}$ & $7.25^{\mathrm{Bab}}$ & $6.00^{\mathrm{BCbc}}$ & $4.67^{\mathrm{CDab}}$ \\
\hline & OMP & $9.00^{\mathrm{Aa}}$ & $7.88^{\mathrm{ABa}}$ & $7.80^{\mathrm{ABa}}$ & $6.67^{\mathrm{Ba}}$ \\
\hline & AA & $8.75^{\mathrm{Aa}}$ & $5.75^{\mathrm{Bb}}$ & $4.80^{\mathrm{BCc}}$ & $4.00^{\mathrm{cb}}$ \\
\hline & $\mathrm{OMP}+\mathrm{AA}$ & $9.00^{\mathrm{Aa}}$ & $6.75^{\mathrm{Bab}}$ & $6.80^{\mathrm{Bab}}$ & $5.33^{\text {BCab }}$ \\
\hline
\end{tabular}

${ }^{1)} \mathrm{UN}$ : untreated; DW: distilled water; OMP: oriental melon peel extracts $0.1 \%$; AA: ascorbic acid $0.1 \%$; OMP+AA: $0.1 \%$ oriental melon peel extracts $+0.1 \%$ ascorbic acid

${ }^{22}$ The value with the same superscripts in columns is not significantly different( $\mathrm{p}<0.05$, Duncan's test). As the value increases from 1 to 9 , the intensity of sensory characteristics increases.

${ }^{33}$ Values with different capital letters(A-F) among mushrooms of same solution during storage days are significantly different at $p<0.05$ based on Duncan's multiple range test.

${ }^{4)}$ Values with different small letters(a-e) among mushrooms of same storage day of different solution are significantly different at $p<0.05$ based on Duncan's multiple range test.

에 대한 $\mathrm{EC}_{50}$ 은 $0.26 \mathrm{mg} / \mathrm{mL}, \mathrm{ABTS}$ 라디칼 소거능에 대한 $\mathrm{EC}_{50}$ 은 $0.76 \mathrm{mg} / \mathrm{mL}$ 로 참외과피추출물은 $\mathrm{ABTS}$ 라디칼 보 다 DPPH 라디칼 소거능에서 좀 더 높은 활성을 나타냈다.

Lee 등(33)의 연구에서 보고한 바와 같이 ABTS 보다 $\mathrm{DPPH}$ 에서 높은 소거활성을 나타냈으며 이는 본 연구결과 와 유사하였다. 최근 연구에 따르면 항산화활성이 우수한 물질은 다양한 기전으로 작용하여 $\mathrm{PPO}$ 와 같은 갈변효소를 불활성화 시킬 수 있는 가능성을 나타내고 있다(27). 본 연구에서는 참외과피추출물의 항산화활성을 확인함으로
Table 2. Sensory properties of Agaricus bisporus dipped by various solutions during storage at $4^{\circ} \mathrm{C}$ for 12 days

\begin{tabular}{|c|c|c|c|c|c|c|}
\hline \multirow{2}{*}{ Attribute } & \multirow{2}{*}{ Sample } & \multicolumn{5}{|c|}{ Storage period (days) } \\
\hline & & 0 & 3 & 6 & 9 & 12 \\
\hline \multirow{5}{*}{ Color } & $\mathrm{UN}^{1)}$ & $9.00^{2) A 3(24)}$ & $6.00^{\mathrm{Ba}}$ & $5.80^{\mathrm{Ba}}$ & $5.33^{\mathrm{Bb}}$ & $5.67^{\mathrm{Ba}}$ \\
\hline & DW & $8.50^{\mathrm{Aa}}$ & $6.75^{\mathrm{ABa}}$ & $6.60^{\mathrm{ABa}}$ & $6.33^{\mathrm{Bab}}$ & $5.67^{\mathrm{BCa}}$ \\
\hline & OMP & $9.00^{\mathrm{Aa}}$ & $7.38^{\mathrm{ABa}}$ & $7.00^{\mathrm{Ba}}$ & $7.67^{\mathrm{ABa}}$ & $6.33^{\mathrm{Ba}}$ \\
\hline & $\mathrm{AA}$ & $8.50^{\mathrm{Aa}}$ & $6.00^{\mathrm{Ba}}$ & $5.80^{\mathrm{Ba}}$ & $6.00^{\mathrm{Bab}}$ & $5.67^{\mathrm{Ba}}$ \\
\hline & $\mathrm{OMP}+\mathrm{AA}$ & $8.50^{\mathrm{Aa}}$ & $6.13^{\mathrm{Ba}}$ & $7.20^{\mathrm{ABa}}$ & $6.00^{\mathrm{Bab}}$ & $6.33^{\mathrm{Ba}}$ \\
\hline \multirow{5}{*}{ Cap opening } & $\mathrm{UN}$ & $9.00^{\mathrm{Aa}}$ & $8.25^{\mathrm{ABa}}$ & $8.20^{\mathrm{ABa}}$ & $7.00^{\mathrm{ABa}}$ & $6.33^{\mathrm{Ba}}$ \\
\hline & DW & $9.00^{\mathrm{Aa}}$ & $8.00^{\mathrm{ABa}}$ & $8.20^{\mathrm{ABa}}$ & $7.00^{\mathrm{ABa}}$ & $6.33^{\mathrm{BCa}}$ \\
\hline & OMP & $9.00^{\mathrm{Aa}}$ & $8.25^{\mathrm{ABa}}$ & $8.20^{\mathrm{ABa}}$ & $7.00^{\mathrm{ABa}}$ & $6.17^{\mathrm{Ba}}$ \\
\hline & $\mathrm{AA}$ & $9.00^{\mathrm{Aa}}$ & $8.00^{\mathrm{ABCa}}$ & $8.20^{\mathrm{ABa}}$ & $7.00^{\mathrm{ABCa}}$ & $6.33^{\mathrm{BCa}}$ \\
\hline & $\mathrm{OMP}+\mathrm{AA}$ & $9.00^{\mathrm{Aa}}$ & $8.25^{\mathrm{ABa}}$ & $8.20^{\mathrm{ABa}}$ & $7.00^{\mathrm{ABa}}$ & $6.33^{\mathrm{Ba}}$ \\
\hline \multirow{5}{*}{ Odor } & UN & $9.00^{\mathrm{Aa}}$ & $8.13^{\mathrm{Aa}}$ & $6.00^{\mathrm{Ba}}$ & $6.00^{\mathrm{Ba}}$ & $5.33^{\mathrm{Ba}}$ \\
\hline & DW & $9.00^{\mathrm{Aa}}$ & $8.25^{\mathrm{ABa}}$ & $6.00^{\mathrm{Ca}}$ & $6.33^{\mathrm{BCa}}$ & $4.50^{\mathrm{Ca}}$ \\
\hline & $\mathrm{OMP}$ & $9.00^{\mathrm{Aa}}$ & $8.25^{\mathrm{ABa}}$ & $6.60^{\mathrm{BCa}}$ & $6.67^{\mathrm{BCa}}$ & $4.50^{\mathrm{Ca}}$ \\
\hline & $\mathrm{AA}$ & $9.00^{\mathrm{Aa}}$ & $8.25^{\mathrm{Aa}}$ & $5.80^{\mathrm{Ba}}$ & $5.67^{\mathrm{Ba}}$ & $5.33^{\mathrm{Ba}}$ \\
\hline & $\mathrm{OMP}+\mathrm{AA}$ & $9.00^{\mathrm{Aa}}$ & $8.25^{\mathrm{Aa}}$ & $5.80^{\mathrm{Ba}}$ & $6.00^{\mathrm{Ba}}$ & $5.33^{\mathrm{Ba}}$ \\
\hline \multirow{5}{*}{ Texture } & $\mathrm{UN}$ & $9.00^{\mathrm{Aa}}$ & $7.88^{\mathrm{ABa}}$ & $7.20 \mathrm{~B}^{\mathrm{Ca}}$ & $6.00^{\mathrm{Ca}}$ & $5.50^{\mathrm{Ca}}$ \\
\hline & DW & $9.00^{\mathrm{Aa}}$ & $8.00^{\mathrm{ABa}}$ & $7.40 \mathrm{~B}^{\mathrm{Ca}}$ & $6.33^{\mathrm{Ca}}$ & $5.83^{\mathrm{Ca}}$ \\
\hline & $\mathrm{OMP}$ & $9.00^{\mathrm{Aa}}$ & $8.00^{\mathrm{ABa}}$ & $7.60^{\mathrm{ABa}}$ & $6.00^{\mathrm{Ca}}$ & $5.83^{\mathrm{Ca}}$ \\
\hline & $\mathrm{AA}$ & $8.75^{\mathrm{Aa}}$ & $7.25^{\mathrm{ABa}}$ & $7.40^{\mathrm{ABa}}$ & $6.00^{\mathrm{BCa}}$ & $5.17^{\mathrm{BCa}}$ \\
\hline & $\mathrm{OMP}+\mathrm{AA}$ & $8.75^{\mathrm{Aa}}$ & $8.00^{\mathrm{ABa}}$ & $7.20^{\mathrm{ABa}}$ & $6.33^{\mathrm{BCa}}$ & $5.33^{\mathrm{CDa}}$ \\
\hline \multirow{5}{*}{$\begin{array}{c}\text { Overall } \\
\text { acceptability }\end{array}$} & $\mathrm{UN}$ & $9.00^{\mathrm{Aa}}$ & $6.88^{\mathrm{Bb}}$ & $5.60^{\mathrm{BCa}}$ & $5.00^{\mathrm{Ca}}$ & $5.00^{\mathrm{Ca}}$ \\
\hline & DW & $9.00^{\mathrm{Aa}}$ & $7.25^{\mathrm{ABab}}$ & $5.80^{\mathrm{BCa}}$ & $5.00^{\mathrm{Ca}}$ & $5.33^{\mathrm{BCa}}$ \\
\hline & $\mathrm{OMP}$ & $9.00^{\mathrm{Aa}}$ & $8.13^{\mathrm{ABa}}$ & $6.60^{\mathrm{BCa}}$ & $6.00^{\mathrm{Ca}}$ & $5.50^{\mathrm{Ca}}$ \\
\hline & $\mathrm{AA}$ & $8.75^{\mathrm{Aa}}$ & $6.50^{\mathrm{Bb}}$ & $5.80^{\mathrm{Ba}}$ & $6.00^{\mathrm{Ba}}$ & $5.33^{\mathrm{BCa}}$ \\
\hline & $\mathrm{OMP}+\mathrm{AA}$ & $9.00^{\mathrm{Aa}}$ & $7.25^{\mathrm{ABab}}$ & $6.60^{\mathrm{Ba}}$ & $5.33^{\mathrm{Ba}}$ & $5.40^{\mathrm{Ba}}$ \\
\hline
\end{tabular}

${ }^{1)} \mathrm{UN}$ : untreated; DW: distilled water; OMP: oriental melon peel extracts $0.1 \%$; AA ascorbic acid $0.1 \%$; OMP+AA: $0.1 \%$ oriental melon peel extracts $+0.1 \%$ ascorbic acid ${ }^{2}$ The value with the same superscripts in columns is not significantly different $(\mathrm{p}<0.05$, Duncan's test). As the value increases from 1 to 9 , the intensity of sensory characteristics increases.

${ }^{3)}$ Values with different capital letters(A-F) among mushrooms of same solution during storage days are significantly different at $p<0.05$ based on Duncan's multiple range test.

${ }^{4)}$ Values with different small letters(a-e) among mushrooms of same storage day of different solution are significantly different at $p<0.05$ based on Duncan's multiple range test.

Table 3. Total phenol and flavonoid contents of oriental melon peel extract

\begin{tabular}{ccc}
\hline & $\begin{array}{c}\text { Total phenol contents } \\
\text { (mg GAE/g) }\end{array}$ & $\begin{array}{c}\text { Total flavonoid contents } \\
\text { (mg QE/g) }\end{array}$ \\
\hline Oriental melon peel & $4.81 \pm 0.64^{1)}$ & $1.18 \pm 0.01$ \\
\hline
\end{tabular}

${ }^{1}$ Each value represented mean $\pm \mathrm{SD}(\mathrm{n}=3)$.

써 양송이에 처리하였을 때 항산화 반응으로 인한 갈변저해 효과가 있었던 것으로 사료된다. 
Table 4. $\mathrm{EC}_{50}$ values in different antioxidant assays and $\mathrm{IC}_{50}$ value in PPO inhibition activity of oriental melon peel extract and ascorbic acid

\begin{tabular}{lcccc}
\hline & & $\mathrm{EC}_{50}{ }^{1)}$ Values & $\mathrm{IC}_{50}{ }^{2)}$ Value \\
\cline { 2 - 5 } Samples & DPPH radical scavenging activity & ABTS radical scavenging activity & Copper chelating activity & PPO inhibition activity \\
\hline Oriental melon peel & $0.26 \pm 0.01^{3)}$ & $0.76 \pm 0.01$ & $0.70 \pm 0.03$ & $0.33 \pm 0.05$ \\
Ascorbic acid & $0.01 \pm 0.00$ & $0.10 \pm 0.01$ & $0.20 \pm 0.00$ & $0.01 \pm 0.00$ \\
\hline
\end{tabular}

${ }^{1)} \mathrm{EC}_{50}$ value is the term half maximal effective concentration, \%

${ }^{2)} \mathrm{IC}_{50}$ value is the term half maximal inhibitory concentration, \%

${ }^{3)}$ Each value represented mean \pm SD $(n=3)$.

\section{구리 킬레이트 활성과 PPO 저해활성}

금속 킬레이트제로 사용되고 있는 폴리페놀 등은 $\mathrm{Fe}^{2+}$, $\mathrm{Cu}^{2+}$ 등 과 같은 산화촉진제를 킬레이트하여 유리 라디칼의 형성을 억제한다고 알려져있다(37). 갈변효소인 PPO는 2가 이온으로 구리를 함유하고 있다. 따라서 구리 킬레이트 활 성을 나타내는 물질이 $\mathrm{PPO}$ 의 구리를 킬레이트하여 직접적 으로 $\mathrm{PPO}$ 를 불활성화 시킬 수 있는 가능성을 가지고 있기 때문에 본 연구에서는 구리 킬레이트 활성과 PPO 저해활성 을 확인하였다. 참외과피추출물의 구리킬레이트 활성의 $\mathrm{EC}_{50}$ 은 $0.70 \mathrm{mg} / \mathrm{mL}$ 로 나타났고, $\mathrm{PPO}$ 저해활성의 $\mathrm{IC}_{50}$ 은 $0.33 \mathrm{mg} / \mathrm{mL}$ 이다(Table 4). 양성대조군으로 사용한 ascorbic acid에 비해 낮은 활성을 보였지만, 양송이에 적용하였을 경우 ascorbic acid보다 참외과피추출물이 표면색 유지에 효과적이었던 것으로 보아 참외과피추출물이 구리 킬레이 트 활성 및 $\mathrm{PPO}$ 저해활성과 항산화활성 등이 상호작용하여 양송이의 저장 중 표면색 변화를 방지하는데 효과적인 것으 로 사료된다.

\section{요 약}

참외과피추출물의 천연갈변저해제로서의 가능성을 확 인하기 위하여 참외과피추출물 및 ascorbic acid를 적용한 양송이의 저장 중 품질변화를 확인하였다. 양송이를 각 처 리구별 PP film으로 포장하여 4 및 $15^{\circ} \mathrm{C}$ 에서 저장하면서 포장 내 기체조성, 경도, 표면 색 및 관능평가를 관찰하였다. 그 결과 기체조성 또는 경도의 변화에 있어서는 처리구별 큰 차이 없이 저장온도 또는 포장재에 따른 영향을 받았으 나, 갈변저해효과에 있어서는 참외과피추출물을 처리하였 을 때 양성대조군으로 사용한 ascorbic acid 보다 표면 색 유지에 효과적이었다. 또한 관능평가에서도 참외과피추출 물을 적용한 처리구(OMP, OMP+AA)에서 저장기간 동안 높은 점수를 유지하였다. 참외과피에 함유되어있는 총 페 놀과 플라보노이드의 함량을 조사한 결과, 참외과피추출물 의 총 페놀함량은 플라보노이드 함량보다 4 배 정도 높게 나타났다. 참외과피추출물의 항산화 및 항갈변 활성은 $\mathrm{DPPH}$ 라디칼 소거활성과 $\mathrm{PPO}$ 저해활성이 낮은 농도에서 도 높은 활성을 나타냈으나 ABTS 라디칼 소거활성과 구리
킬레이트 활성에서는 비교적 높은 농도에서 활성을 보였 다. 이에 따라 참외과피추출물을 천연갈변저해제로서 양송 이에 적용하였을 때 효과적으로 양송이의 갈변을 저해할 수 있음을 확인하였다.

\section{감사의 글}

본 연구는 농촌진흥청 공동연구사업의 연구비 지원(PJ 906939042013)과 일부는 2013년도 정부(교육과학기술부) 의 재원으로 한국연구재단의 대학중점연구소 지원 사업으 로 수행된 연구(2009-0094917)로 이에 감사드립니다.

\section{References}

1. Park SS, Lee KD, Min TJ (1995) Study on the screening development of antibiotics in the mushrooms. Korean $\mathbf{J}$ Mycol, 23, 176-189

2. Ministry of agriculture and forestry (2011) Agriculture and Forestry statistical year book. Republic of Korea

3. Ahn YS, Shin DH, Kang CH, Oh SW (2000) Studies on oyster mushroom (Pleurotus ostreatus) packed in various environmental friendly trays. Korean Soc Food Sci Nutr, 29, 85-92

4. Kim BS, Park SY, Jang MS, Kwon AS (2007) Effect of prolongation by precooling treatment and improved packing of mushrooms (Agaricus bisporus). Korean $\mathbf{J}$ Food Preserv, 14, 109-112

5. Lee DU, Chang MS, Cho SD, Jhune CS, Kim GH (2013) Quality changes in mushrooms (Agaricus bisporus) due to their packaging materials during their storage. Korean J Food Preserv, 20, 7-13

6. Yim SB, Kim MO, Koo SJ (1991) Determination of dietary fiber contents in mushrooms. Korean J Soc Food Sci, 7, 69-76

7. Mccord JD, Kilara A (1983) Control of enzymatic browning in processed mushrroms (Agaricus bisporus). 
J Food Sci, 48, 1479-1484

8. Coesteng My, Lee CY (1987) Changesin apple polyphenoloxidase and polyphenol concentrations in relation to degree of browning. J Food Sci, 52, 985-989

9. Lee JY, Park HJ, Lee CY, Choi WY (2003) Extending shelf-life of minimally processed apples with edible coatings and antibrowning agents. Lebensm-Wiss $\mathrm{U}$ Technol, 36, 323-329

10. Ryu JM, Park YJ, Choi SY, Hwang TY, Oh DH, Moon KD (2003) Browning inhibition and quality characteristics of minimally processed msuhroom (Agaricus bisporus Sing) using extracts form natural materials during storage. Korean J Food Preserv, 10, 11-15

11. Chang MS, An S, Jeong MC, Kim D, Kim GH (2011) Effects of antioxidative activities and antibrowning of extracts from onion, apple and mandarin orange peel as natural antibrowning agents. Korean J Food Nutr, 25, 406-413

12. Son SM, Moon KD, Lee CY (2000) Rhubarb juice as a natural anti-browning agent. J Food Sci, 14, 32-37

13. Kim HS, Kang YH (2010) Antioxidant activity of ethanol extracts of non-edible parts (stalk, stemleaf, seed) from oriental melon. Korean J Plant Res, 23, 451-457

14. Shin YS, Lee JE, Yeon IK, Do HW, Cheung JD, Kang CK, Choi SY, Youn SJ, Cho JG, Kwoen DJ (2008) Antioxidant and antimicrobial effects of extract with water and ethanol of oriental melon (Cucumis melo L. var makuwa Makino). Korean J Soc Appl Biol Chem, 51, 194-199

15. Minamide $T$, Iwata $T$, Habe $T$ (1985) Studies on physiological, chemical properties and post-harvest keeping quality of mushrooms IX. changes in soluble carbohydrates and keeping the freshness of mushrooms (Agaricus bisporus SING.) after harvest. Bull Univ Osaka Pref Ser B Agric Biol 37, 5-11

16. Kader AA (1985) Postharvest biology and technology an overview. In: Postharvest technology of horticultural crops, The reagent of the University of California, Division of agricultural and nutritional resource, CA, USA, p 3-8

17. Florence CRF, Pascale MG, Jacques JN (1992) Cystenine as an inhibitor of enzymatic browning. 2 kinetic studies. J Agric Food Chem, 40, 2108-2113

18. Lin JY, Tang CY (2007) Determination of total phenolic and flavonoid contents in selected fruits and vegetables, as well as their stimulatory effects on mouse splenocyte proliferation. Food Chem, 101, 140-147
19. Blois MS (1985) Antioxidant activity determination by the use of a stable free radical. Nature, 181, 1199-1200

20. Pellegrin N, Chiavaro E, Gardana C, Mazzeo T, Contino D, Gallo M, Riso P, Fogliano V, Porrii M (2010) Effect of different cooking methods on color, phytochemical concentration, and antioxidant capacity of raw and frozen brassica vegetables. J Agric Food Chem, 58, 4310-4321

21. Custodio L, Justo T, Silvestre L. Barradas A, Duarte CV, Pereira H, Barreira L, Rauter AP, Albericio F, Varela J (2012) Microalgae of different phyla display antioxidant, metal chelating and acetylcholinesterase inhibitory activities. Food Chem, 131, 134-140

22. Dennis D, Miller JW (1998) Enzymatic browning. In: Kinetics of tyrosinase. J Agric Food Chem, 30, 44-49

23. Gorny JR, Hess-Pierce B, Kader AA (1998) Effect of fruit ripeness and storage temperature on the deterioration rate of fresh-cut peach and nectarine slices. Hort Sci, 33, 110-113

24. Chung HS, Moon GD (2012) Effect of browning inhibition on quality property of fresh-cut strawberries. Korean J Food Preserv, 19, 26-30

25. Wallner SJ (1978) Apple fruit $\beta$-galactosidase and softening in storage. J Amer Soc Hort Sci, 103, 364-366

26. Lopez-Briones G, Varoguaux P, Chambroy Y, Bouquant J, Bureau G, Pascat B (1992) Storage of common mushroom under controlled atmospheres. Intl J Food Sci Technol, 27, 493-505

27. Park M, Chang MS, Jeong MC, Kim GH (2013) Scutellaria baicalensis extracts as natural inhibitors of food browning. J Korean Soc Food Sci Nutr, 42, 792-799

28. Lee DU, Kim GH (2013) Browning inhibition effect of the Atractylodis Rhizoma Alba extract and L-cysteine combination on Agaricus bisporus. Korean J Food Preserv, 20, 173-181

29. Droge W (2001) Free radicals in the physiological control of cell function. Physiol Rev, 82, 47-95

30. Halliwell B, Aeschbach R, Loliger J, Aruoma OI (1995) The characterization of antioxidants. Food Chem Toxicol, 33, 601-617

31. Shivraj HN, Khobragade CN (2010) Antioxidant activity and flavonoid derivatives of Plumbago zeylanica. J Natural Prod, 3, 130-133

32. Peter CH Hollman, John MP van Trijp, Michel NCP Buysman, Martijin S Gaag, Marcel JB Mengelers, Jeanne HM Bries, Martijin B Katan (1997) Relative bioavailability of the antioxidant flavonoid quercetin from various foods in man. FEBS letters, 418, 152-156 
33. Lee MY, Yoo MS, Whang YJ, Jin YJ, Hong MH, Pyo YH (2012) Vitamin C, total polyphenol, flavonoid contents and antioxidant capacity of several fruit peels. Korean J Food Sci Technol, 44, 540-544

34. Tsao R (2010) Chemistry and biochemistry of dietary polyphenols. Nutrients, 2, 1231-1246

35. Rice-Evans CA, Miller NJ, Paganga G (1997) Antioxidant properties of phenolic compounds. Trends Plant Sci, 2, 152-159
36. Kim EJ, Choi JY, Yu MR, Kim MY, Lee SH, Lee BH (2012) Total polyphenols, total flavonoid contents, and antioxidant activity of Korean natural and medicinal plants. Korean J Food Sci Technol, 44, 337-342

37. Wong JY, Chye FY (2009) Antioxidant properties of selected tropical wild edible mushroom. J Food Comos Anal, 22, 269-277

38. Lester G. (1997) Melon (Cucumis melo L.) fruit nutritional quality and health functionality. Hort Technol, 7, 222-227

(접수 2014년 2월 3일 수정 2014년 3월 19일 채택 2014년 8월 5일) 